UDK: 502.12:373.2.011.3-057.875

Original scientific paper

\title{
UNDERSTANDING SUSTAINABLE DEVELOPMENT AND PRO- ECOLOGICAL BEHAVIOUR OF FUTURE PRESCHOOL TEACHERS
}

\author{
Jasmina Hadela \\ Early Childhood Development Center Čakovec \\ Republic of Croatia \\ jhadela2306@gmail.com \\ Alen Hasikić \\ Faculty of Educational Sciences \\ Juraj Dobrila University of Pula \\ Republic of Croatia \\ alen.hasikic@unipu.hr
}




\section{ABSTRACT}

This paper determines sustainable development and emphasizes the importance of educational institutions in proclaiming sustainable development. Furthermore, a research was conducted with the aim of determining an understanding of sustainable development concepts and the familiarity with certain terms as well as the frequency of certain pro-ecological behaviour in future preschool teachers. The sample consisted of undergraduate students of Early and Preschool Education of the University of Zagreb $(N=266)$. According to the results obtained, future preschool teachers agree that today's society should strive for sustainable development. In addition, future preschool teachers mostly practice those pro-ecological behaviours that relate to energy and water saving.

Key words: sustainable development, educational institution, research, future preschool teachers, pro-ecological behaviours. 


\section{INTRODUCTION}

Educational institutions play an important role in fostering and building knowledge and skills, as well as shaping the awareness, values and actions of individuals related to sustainability, which are required in order to achieve the goals necessary for a sustainable future on Earth. In that sense, educational institutions should educate future preschool teachers to understand sustainability better, and to help bridge the gap between theory and education. This will afterwards play a key role in shaping future generations, taking actions regarding sustainability and taking responsibility for their actions. (Keles, 2017). Individuals spend about one third of their lives in schools, shaping their personality, which is difficult to change later in life. Preparing students for future life requires, above all, active teaching and successful learning. Later integration into society largely depends on their qualities and competencies, which expand and upgrade as a result of wellorganized and accomplished education. This includes a pleasant and motivating atmosphere with a high level of mutual understanding, research cooperation in learning and the possibility of acquiring certain knowledge through all courses which should strive for an interdisciplinary approach in teaching (Kostova, Atasoy, 2008). Guided by the goal of education for sustainable development, which emphasizes the improvement of knowledge, development of individual skills and their commitment to sustainable development, it is necessary to systematically and actively involve individuals in many life situations and situations within the education period, those in which they will learn and understand modern life challenges that arise as a result of different social, cultural and economic influences. In that sense, education for sustainable development strives for the kind of teaching that is centred around an individual person (pupil, student), and that provides such a learning environment in which one can think about reality, develop its own ideas and values (Popović, 2015).

Climate change, reckless use of non-renewable energy sources, natural disasters and environmental pollutions are only a part of the issues being studied in the concept of sustainable development. The concept of sustainability itself is very wide, and in modern times, for many, still an insufficiently clear concept.

Often, sustainable development is terminologically identified only with ecological projects and activities (Pejanović, 2014). However, sustainable development has been a much more complex concept and ever since the year 1987 until today, one of the key elements in formulating and implementing world-wide development policies (Pavić-Rogošić, 2010). Therefore, the question arises: What does the sustainable development concept actually represent? It is 
important to emphasize that "the meaning and understanding of sustainable development depends primarily on the basis, values and interests of those who are considering it" (Rončević and Rafajac, 2012, 7). Starting from defining the concept of sustainable development, the most commonly mentioned definition (Anđić, 2007; Cifrić, 2001; Herceg, 2013; Rončević, Ledić and Ćulum, 2008; Summers and Cutting, 2016) is by Our Common Future, Brundtlandine's World Commission for Environment and Development, from the year 1987. According to the report, sustainable development is "a development that meets the needs of the present without compromising the possibilities of future generations to meet their needs". Although this definition has often been criticized as vague, it is a good way to shape thinking about what one wants to develop in order to have an impact over a longer period of time. Mebratu (1998, according to Mathebula, 2018) points out that two key concepts are embedded within the definition, and they relate to: (1) the concept of needs, in particular the essential needs of the world's poor, to which priority should be given; and (2) the concept of limitations, particularly limitations imposed on the natural environment to survive the impact of human activities on it or the ability to renew its resources. Put that way, it cannot be said with absolute certainty that development efforts have a positive effect or improve the lives of human beings, if the needs of the poor are neglected or the possibilities of restoring the environment are limited in order to meet the future needs of human and nonhuman lives. Therefore, anyone driven by a long lasting personal interest or concern for poverty or intergenerational equity, would likely be willing to support the operational objectives arising from the definition of sustainable development. Such a broad definition of sustainable development is committed to consensus, as it is based on scientific evidence of environmental degradation, moral and ethical principles of poverty, and considerations of long-term self-interest (Mathebula, 2018).

Given that the role of future preschool teachers is unquestionable, it is important to gain an insight into their understanding of sustainable development, and consequently their pro-environmental behaviour as a part of sustainable development. Preschool teachers are the ones who will raise and educate future generations and it is therefore extremely important that they themselves raise awareness of the necessity of caring for the environment, people and the economy.

Previous research on the sustainable development concept state that students generally understand the issue and accept the concept of sustainability, but do still not have a defined opinion on how and in what ways sustainable development could be achieved (Rončević, Rafajac, 2012). In their research, Rončević, Ledić and Ćulum (2008) have found that students have little knowledge of the 
concept of sustainable development and most of them identify this concept with environmental protection. Furthermore, Boon (2010), in her research with future preschool teachers in Queensland, came to findings that final year students had unacceptably little knowledge about climate change and the students themselves stated that they were not certain if they could talk about these concepts in their future work.

When it comes to pro-ecological behavior, one can say that it is a behaviour that consciously seeks to minimize the negative impact of its actions on nature and the constructed world (Kollmuss, Agyeman, 2002). The same authors state that pro-ecological behaviour can be seen as a complex network of ecological, economic and social elements that determine the lives of future generations.

More common theoretical models that seek to interpret pro-ecological behaviours are the theory of reasoned action by Eisen and Fishebein (1980), which later developed into the theory of planned behaviour (Eisen, 1991), and also the theory of ecological value (Schwartz, 1977), and Stern's theory of pro-ecological behaviour.

According to the theory of reasoned action, attitudes are formed in accordance with the belief of an individual that his action will have a result. Human behavior is influenced by a person's attitude and subjective norm, according to this theory. In a pro-ecological context, pro-ecological behaviour is influenced by a person's attitude toward that type of behaviour and their own perception of how the environment evaluates one's behaviour. Next, the theory of planned behaviour, includes a third factor that affects pro-ecological behaviour, i.e. perceived behavioural control. It is a measure that shows human assessment of the difficulty of performing a behaviour (Eisen, 1991). This theory implies an individual's level of control over the realization of a particular behaviour.

The theoretical approach to ecological value has its foundations in the work of Shalom Schwartz (1977), according to Anđić, Tatalović Vorkapić, 2015). This approach distinguishes a value system that is oriented towards oneself and the fulfillment of one's own interests (egoistic orientation), in which the probability of ecological action and prosocial orientation, which represents orientation towards the environment, are lower.

When looking at scientific research related to the research of this issue, Cifrić (1997) conducted empirical research on ecological behaviour at four faculties at the University of Zagreb. The findings show that the largest percentage of students practice ecological behaviour such as: selection and recycling, buying less harmful products and saving electricity and water. A small number of students support ecological manifestations, read ecological literature or are a member of an 
ecological association. Recent research (Rončević, Cvetković, 2016) shows that the largest number of students, as part of pro-environmental behavior, usually turn off the light before leaving the room, and turn off the air conditioning or heating before opening the window. The purchase of organic fruit turned out to be the least common pro-ecological behaviour among students. In the Chilean context, Heyl, Diaz, Cifuentes (2013) also investigated students' pro-ecological behaviours and found that students recycled paper and bought recycled products least, and they minimally purchased organic products, while the most common pro-ecological behaviours were turning off the tap and turning off the light.

Having this in mind, in order to gain an insight into the situation among students - future preschool teachers, the aim of this paper is to examine the understanding of the sustainable development concept and the frequency of proecological behaviour in undergraduate students of Early and Preschool Education at the University of Zagreb.

\section{RESEARCH METHODOLOGY}

\subsection{Research aim}

The aim of this research was to determine the understanding of sustainable development concept and familiarity with certain terms as well as the frequency of specific pro-ecological behaviour of undergraduate students (future preschool teachers) of Early and Preschool education at the University of Zagreb.

\subsection{Specific research questions}

Based on the research aim and a review of available research, the following specific research questions have been set:

1. On which statement of understanding sustainable development do future preschool teachers show the highest degree of agreement?

2. Do future preschool teachers differ in their understanding of sustainable development regarding to the independent variables - age, year of study, place of living, quality of life and their parents level of education?

3. Are future preschool teachers familiar with terms related to sustainable development?

4. Which pro/non-ecological behaviours do future preschool teachers express as the most common, and which as the rarest? 
5. Do future preschool teachers differ in their pro/non-ecological behaviours regarding the independent variables - age, year of study, place of living, quality of life and their parents level of education?

\subsection{Research hypotheses}

According to previous research, the following hypotheses have been set: H1: Future preschool teachers show the highest degree of agreement with the statement that sustainable development is the intergenerational solidarity and concern of the present generations for the needs of future generations.

$\mathrm{H} 2$ : There are statistically significant differences in the understanding of sustainable development regarding the independent variables - age, year of study, place of living, quality of life, and parents level of education.

H3: Future preschool teachers are familiar with the terms of sustainable development, but if they were supposed to explain it, they would not know how H4: As the most common pro-ecological behaviours, the future preschool teachers point out those related to saving energy and water, and as the rarest the purchase of organic produced food

H5: There are statistically significant differences in the responses of future preschool teachers in pro/non-ecological behaviors regarding the independent variables.

\subsection{Research instrument}

For the purposes of this research, an online survey was created which consisted of four parts: (1) general data; (2) understanding the concept of sustainable development; (3) self-assessment of familiarity with concepts related to sustainable development; (4) pro-ecological behaviours. In the first, general part, the participants had to state their gender, age, year of study, place of living, quality of life in relation to others, and their parents' level of education.

The second part, understanding the concept of sustainable development, consisted of eight items taken from the research of Rončević and Rafajac (2012). Prior to the research, a written request was sent to the authors for the use of this scale which they approved. Participants were required to state their agreement with each statement on a 5 -point Likert-type scale ( 1 - strongly disagree, 5 - strongly agree). A factor analysis was performed on the given scale in order to determine the structure of the items and the justification for the use of the specified scale in this study. Since the Kaiser-Meyer-Olkin (KMO) test was 0.859 and the Bartlett test of sphericity was statistically significant $(\chi 2=800.999$; $\mathrm{df}=28, \mathrm{~N}=266$, $\mathrm{p}<0.001$ ), the basic prerequisites for continuing the factor analysis were met. The 
basic solution extracted two factors, which explain $63.02 \%$ of the total variance, but by examining the Scree plot and saturating the particles, the one-factor structure of this scale was retained. The one-factor structure explains $46.34 \%$ of the total variance. The reliability of the scale in this study was measured by the Cronbach $\alpha$ coefficient which equaled $\alpha=.808$.

The third part of the survey was taken from the research of Effeney and Davis (2013, according to Vukelić, Rončević, Vinković, 2018). In order to examine the perceived knowledge of concepts related to sustainable development, this part of the survey was translated in the Croatian scientific community, where authors Vukelić, Roncević, Vinković (2018) applied the scale in researching perceived knowledge of concepts related to sustainable development of future teachers. Participants were asked to circle one of the offered answers for each of the seven terms ( 1 - I have never heard of this term and I am not able to explain it; 2 - I have heard of this term, but I can not exactly explain what it represents; 3 - I know something about this term and I can explain it in general; 4 - I am familiar with this term and I can explain it well). A factor analysis was performed on the scale in order to determine the structure of the items and the justification for the use of the specified scale in this study. Since the Kaiser-Meyer-Olkin (KMO) test was 0.878, and the Bartlett test of sphericity was statistically significant $(\chi 2=810.398 ; \mathrm{df}=21$, $\mathrm{N}=266, \mathrm{p}<0.001$ ), the basic prerequisites for continuing the factor analysis were met. The basic solution extracted the one-factor structure of the mentioned scale, which explains $55.84 \%$ of the total variance. The reliability of the scale in this study was measured by the Cronbach $\alpha$ coefficient which equaled $\alpha=.860$.

The last part consisted of a pro-ecological behaviour scale containing 15 described behaviors related to energy and water saving, waste sorting and recycling, and the purchase of organically grown vegetables. Participants were asked to express the frequency of each behaviour that best describes them on a 5-point Likert scale (1- Never, 5 - Always). This scale was taken from Rončević and Cvetković (2016, adapted according to Bertoldo 2014) who researched the pro-ecological behaviour in the Croatian context, on the student population of the University of Rijeka. A factor analysis was also performed on this scale, to determine the structure of the items and the justification for using this specific scale in this study. Since the KaiserMeyer-Olkin (KMO) test was 0.815 and the Bartlett test of sphericity was statistically significant $(\chi 2=1004.745 ; \mathrm{df}=105, \mathrm{~N}=266, \mathrm{p}<0.001)$, the basic prerequisites for continuing the factor analysis were met. The baseline solution extracted five factors that explain $61.95 \%$ of the total variance. By examining the Scree plot and particle saturation on factors it is established that the one-factor structure should be maintained here as well. Such a structure ultimately explained $29.66 \%$ of the total 
variance. The reliability of this scale in this study was measured by the Cronbach $a$ coefficient which equaled $\alpha=.806$. The total internal consistency of the entire survey is $\alpha=.810$. Table 1 . shows the metric characteristics of these scales.

Table 1. Descriptive indicators of the used scales

\begin{tabular}{lcccccc}
\hline Instruments & $\mathrm{M}$ & $\mathrm{SD}$ & $\mathrm{Min}$ & $\mathrm{Max}$ & $\mathrm{a}$ & $\% \mathrm{~V}$ \\
\hline „Understanding sustainable development“ scale & 3,62 & 0,66 & 1 & 5 & .808 & 46,34 \\
\hline „Familiarity with the terms“ scale & 3,28 & 0,51 & 1,57 & 4 & .860 & 55,84 \\
\hline „Pro-ecological behaviour“ scale & 3,37 & 0,36 & 2,27 & 4,53 & .806 & 29,66 \\
\hline
\end{tabular}

\subsection{Sample and research implementation}

The sample in this research consists of undergraduate students of Early and preschool education at the University of Zagreb $(\mathrm{N}=266)$, attending $t$ he first and the third year of study. The survey was conducted from March to May 2020, via an online form posted on the distance learning system Merlin. The purpose and the aim of the research were explained to the students and the anonymity and confidentiality of the obtained data were guaranteed. All data were transferred to the database and than processed and analyzed in the statistical program SPSS IBM 24. Parametric tests were used in the study since a normal distribution of results was obtained. A t-test for independent groups was used to determine the statistical significance of the average results of the two groups, while a one-way analysis of variance for independent samples was performed to determine the statistical significance of the average results of several groups, along with the post hoc tests Hochberg GT2 for homogeneous samples and Games-Howell for inhomogeneous samples (Field, 2013). Statistical significance was measured by the effect size. where 0.01 to 0.05 is the small effect size, 0.06 to 0.13 is the medium effect size, and 0.14 is the large effect size (Petz, Kolesarić, Ivanec, 2012). All tests were performed at a risk level of $5 \%$.

According to the available data, $60.9 \%$ of students $(\mathrm{N}=162)$ attend the first year, and $39.1 \%$ of students $(\mathrm{N}=104)$ the third year of full-time undergraduate Early and Preschool Education study (hereinafter: future preschool teachers). According to the gender structure, $97.4 \%$ of participants were future female preschool teachers $(\mathrm{N}=259)$, and $2.6 \%$ were future male preschool teachers $(\mathrm{N}=7)$. Furthermore, $35.3 \%$ of the participants $(\mathrm{N}=94)$ were between 18 and 19 years old, $38.7 \%$ of the participants $(\mathrm{N}=103)$ were between 20 and 21 years old, and $25.9 \%$ of the participants $(\mathrm{N}=69)$ were between 22 and 25 years old. When asked where they spent most of their lives, $37.2 \%$ of the participants $(\mathrm{N}=99)$ stated 
that they spent most of their lives in a rural area, $21.4 \%$ of them $(\mathrm{N}=57)$ in a small town $(<30,000$ inhabitants) and $43.6 \%$ of the participants $(\mathrm{N}=110)$ in a large city (> 30,000 inhabitants). When examining the parents' level of education, the results indicate that the highest percentage of both mothers and fathers of future preschool teachers have completed secondary education.

Assessing the quality of life compared to most other people, participants mostly (69.9\%) stated that they did not live better or worse than most other people. As many as $27.4 \%$ of them stated that they lived better and much better than most other people, and a smaller number (2.6\%) stated that they lived worse than most other people. The reason these independent variables were used in this study is because in previous studies (Rončević, Rafajac, 2012; Rončević, Cvetković, 2016) they proved to be statistically significant in understanding sustainable development and pro-ecological behaviour of students of different study fields at the University of Rijeka.

\subsection{Results and discussion}

In order to answer the first two specific aims of the research and to test the first and second hypotheses, the descriptive data on the scale of understanding the concept of sustainable development are presented, and after that the results of inferential statistics. Table 2. shows the descriptive data of the given scale.

Table 2. Descriptive parameters on the scale of understanding the concept of sustainable development ( $\mathrm{M}$ i SD)

\begin{tabular}{lcc}
\hline & M & SD \\
\hline $\begin{array}{l}\text { Sustainable development seeks to balance the magic triangle: } \\
\text { environmental protection, stable economic development and a fair } \\
\text { distribution of social opportunities }\end{array}$ & 4.11 & 1.01 \\
\hline $\begin{array}{l}\text { Sustainable development implies intergenerational solidarity and care of } \\
\text { the present generations for the needs of future generations. }\end{array}$ & 4.13 & 1.05 \\
\hline $\begin{array}{l}\text { Today's society should strive for sustainable development. } \\
\text { Sustainable development is a political phrase and an empty formula. }\end{array}$ & 4.42 & .95 \\
\hline $\begin{array}{l}\text { Sustainable development strives for democracy, peace and poverty } \\
\text { reduction. }\end{array}$ & 3.62 & 1.02 \\
\hline $\begin{array}{l}\text { Sustainable development refers only to the ability to use natural resources } \\
\text { responsibly, i.e. to environmentally conscious behavior. }\end{array}$ & 2.88 & 1.09 \\
\hline $\begin{array}{l}\text { The implementation of the ideas of sustainable development is only } \\
\text { possible with a profound change in values and political concepts. }\end{array}$ & 3.42 & 1.11 \\
\hline $\begin{array}{l}\text { In order to control environmental problems, people must be willing to } \\
\text { radically change their own behaviour and attitudes. }\end{array}$ & 4.03 & 1.05 \\
\hline
\end{tabular}


According to the obtained data, it is noticed that the largest percentage of future preschool teachers show agreement $(\mathrm{M}=4.42 ; \mathrm{SD}=.95)$ with the statement that today's society should strive for sustainable development. Furthermore, a high degree of agreement was obtained on the statement that sustainable development implies intergenerational solidarity and care of the current generation for the needs of future generations $(\mathrm{M}=4.13 ; \mathrm{SD}=1.05)$ and that sustainable development seeks to balance the magic triangle $(\mathrm{M}=4.11 ; \mathrm{SD}=1.01)$. Given that the statement regarding sustainable development implies intergenerational solidarity and care of the current generation for the needs of future generations is one of the most common explanations for sustainable development, it was assumed that future students will agree with this statement, as was obtained in the research with students and teachers at the University of Rijeka (Rončević, Rafajac, 2012). Although the highest degree of agreement was observed on the statement that today's society should strive for sustainable development, it can be pointed out that this is a general statement and as such does not necessarily mean that future preschool teachers understand its meaning. Therefore, it can be said that the first hypothesis was confirmed because if excluding this general statement, it is obvious that the next highest one, is the exact one which was stated in the previous research.

In addition to the above, future preschool teachers show high agreement with the statement that in order to control environmental problems, people must be willing to radically change their own behaviour and attitudes $(\mathrm{M}=4.03$; $\mathrm{SD}=1.05)$. In her research Uzelac (2002) also came to similar results where $44.9 \%$ of participants agreed, and $42.1 \%$ strongly agreed with the statement that the ecological crisis can only be overcome by changing one's own lifestyle, especially in terms of consumer lifestyle. Similar results were obtained by Rončević and Rafajac (2012) where more than half of the students of the University of Rijeka pointed out their agreement with this statement. Furthermore, the lowest agreement $(\mathrm{M}=2.32 ; \mathrm{SD}=.97)$ was observed on the statement that sustainable development is a political syntagm and an empty formula, which also corresponds to the research of Rončević and Rafajac (2012). Most future preschool teachers are indecisive or agree with the statement that the implementation of sustainable development is possible only with a profound change in values and political concepts $(\mathrm{M}=3.42$; $\mathrm{SD}=1.11)$. Similar results, where half of the students thought that without initial activity from the political level the promotion of the idea of sustainable development was not possible, were obtained in the preliminary examination of students' attitudes towards sustainable development (Rončević, Ledić, Ćulum, 2008).

In order to determine whether there are statistically significant differences in the understanding of sustainable development regarding independent variables, a 
t-test for independent samples and an analysis of variance for independent samples were performed.

The implementation of the t-test found that there is a statistically significant difference on three of the eight statements regarding the year of study. A statistically significant difference was found on the statement that sustainable development is a political syntagm and an empty formula $(\mathrm{t}(264)=3.413, \mathrm{p}<0.01)$. The first-year students showed a more statistically significant agreement with the above statement $(\mathrm{M}=2.48$; $\mathrm{SD}=.96)$ than the third-year students $(\mathrm{M}=2.07$; $\mathrm{SD}=.94)$. The effect size index $(\eta 2=0.042)$ indicates that only $4.2 \%$ of the variance of participants' agreement that sustainable development is a political syntagm and an empty formula can be related to the year of study. Moreover, a statistically significant difference was found on the statement that sustainable development strives for democracy, peace and poverty reduction $(\mathrm{t}(264)=2.430$, $\mathrm{p}<0.05$ ) where the first-year students show greater agreement with this statement $(\mathrm{M}=3.74 ; \mathrm{SD}=.94)$ versus the third-year students $(\mathrm{M}=3.43 ; \mathrm{SD}=1.11)$. The effect size index ( $\eta 2=0.022)$ indicates that only $2.2 \%$ of the variance of the participants agreement that sustainable development strives for democracy, ensuring peace and reducing poverty can be related to the year of study. The last statistically significant difference was found on the statement that sustainable development refers only to the ability to use natural resources responsibly, i.e. environmentally conscious behaviour $(\mathrm{t}(264)=2,574, \mathrm{p}<0.05)$, where first-year students show a higher degree of agreement $(M=3.01 ; S D=1.09)$ versus the third year students $(M=2.66$; $\mathrm{SD}=1.07)$. The efect size index $(\eta 2=0.024)$ indicates that only $2.4 \%$ of the variance of the respondents agreement that sustainable development refers only to the ability to use natural resources responsibly, ie. environmentally conscious behaviour, can be associated with the year of study.

No statistically significant difference was found between the responses of future preschool teachers in relation to other independent variables. What is interesting in this research, the first-year students show a statistically higher degree of agreement with individual statements than the final-year students, which was not the case with students in the research conducted by Rončević and Rafajac (2012). In their research the final-year students showed a higher degree of agreement, and the authors concluded that it is probably due to the level of information. Here it can be considered that first-year students may have speculated or given socially desirable answers to certain questions. Therefore, the second hypothesis is only partially confirmed, since the statistically significant difference in the understanding of the sustainable development concept by the future preschool teachers was not confirmed on other independent variables in this research. 
The third specific aim refers to the familiarity of the participants with the terms related to sustainable development. Table 3. represents the obtained results. The participants were asked to self-assess familiarity on the four level scale of answers: 1 - I have never heard of this term and I am unable to explain it; 2 - I have heard of this term, but I could not exactly explain what it represents; 3 - I know something about this term and I could explain it in general; 4 - I am familiar with this term and I could explain it well. In the table below it can be seen that the respondents most often chose the answers that they know something about the term and could explain it in general, and that they were familiar with a particular term and could explain it well. Interestingly, as many as $28.2 \%(\mathrm{~N}=75)$ of the participants stated that they had heard of the term greenhouse gases, but could not actually explain it well, as well as nuclear waste where as many as $33.5 \%(\mathrm{~N}=89)$ of participants stated the same. For this term, the least number of participants stated that they were completely familiar with the term and that they could explain it well $(18.8 \%, \mathrm{~N}=50)$. Similar results were obtained by the Effeney and Davis's research (2013), who also indicate that most of the participants can explain the concepts in detail and that they are familiar with them. Vukelić, Rončević, Vinković (2018) came to the same conclusion with students estimating, on average, that they knew something about all these concepts and could explain them in general. Hypothesis three is therefore rejected, given that a large number of future preschool teachers emphasize the familiarity with these concepts, but also the ability to explain them if asked to do so.

Table 3. Self-assessment of familiarity with concepts related to sustainable development $(\%, \mathrm{C}, \mathrm{Q} 3-1)$

\begin{tabular}{lcccccc}
\hline & 1 & 2 & 3 & 4 & $\mathrm{C}$ & $\mathrm{Q}_{3-1}$ \\
\hline Greenhouse gasses & 6.0 & 28.2 & 42.1 & 23.7 & 3.00 & 1.00 \\
\hline Nuclear waste & 2.6 & 33.5 & 45.1 & 18.8 & 3.00 & 1.00 \\
\hline Deforestation & 0.4 & 9.4 & 39.8 & 50.4 & 4.00 & 1.00 \\
\hline Lack of drinking water & 0.4 & 8.3 & 42.3 & 49.1 & 3.00 & 1.00 \\
\hline Climate changes & 0.4 & 6.4 & 42.1 & 51.1 & 4.00 & 1.00 \\
\hline Pollution & 0.0 & 4.9 & 33.1 & 62.0 & 4.00 & 1.00 \\
\hline Extinction of species & 0.8 & 5.6 & 38.3 & 55.3 & 4.00 & 1.00 \\
\hline
\end{tabular}

The last segment explored in this paper is the pro-ecological behaviour of future preschool teachers. According to the data obtained in Table 4, it can be seen that the largest number of participants often or always turn off the lights when leaving the room $(\mathrm{M}=4.68 ; \mathrm{SD}=.62)$, and turn off the air conditioning or heating 
before opening the window $(\mathrm{M}=4.35 ; \mathrm{SD}=.99)$. They also separate and dispose of glass waste in designated containers $(\mathrm{M}=4.10 ; \mathrm{SD}=1.23)$ and pay attention to water consumption at home $(\mathrm{M}=4.09 ; \mathrm{SD}=1.00)$. Given the negative meaning of particular particles, it is important to emphasize that lower average values actually mean more positive behaviour. Therefore most participants stated that they never or rarely forgot to turn off the lights in rooms where no one was in $(\mathrm{M}=1.67$; $\mathrm{SD}=.85)$ and that they rarely or never forgot to separate and dispose of paper in special containers for paper disposal $(\mathrm{M}=1.94 ; \mathrm{SD}=1.18)$. Interestingly, $23.7 \%$ of respondents stated that they sometimes found it boring to separate and dispose of garbage for recycling, and $42.9 \%$ stated that they only sometimes bought fruit grown in organic production. Greater dispersion of responses can be seen in the statement that participants turn off appliances (computer, mobile phone) rather than leaving them on the charger and in the statement that batteries are thrown into containers specially marked for this purpose.

Table 4. Pro-ecological behaviours of future preschool teachers

\begin{tabular}{lcc}
\hline & $\mathrm{M}$ & $\mathrm{SD}$ \\
\hline $\begin{array}{l}\text { I turn off the appliances (computer, cell phone) rather than leaving them } \\
\text { on the charger. }\end{array}$ & 3.37 & 1.30 \\
\hline I turn off the lights when I leave the room. & 4.68 & .62 \\
\hline I use energy saving light bulbs. & 3.98 & 1.02 \\
\hline I turn off the air conditioning or heating before opening the window. & 4.35 & .99 \\
\hline At home, I watch my water consumption. & 4.09 & 1.00 \\
\hline $\begin{array}{l}\text { I find separating and disposing of garbage for recycling on eco-islands } \\
\text { boring }\end{array}$ & 2.11 & 1.13 \\
\hline I throw batteries in containers specially marked for this purpose. & 3.81 & 1.32 \\
\hline I forget to turn off the lights in rooms where no one is in. & 1.67 & .85 \\
\hline I turn off electrical appliances so they won't be in standby mode. & 3.62 & 1.26 \\
\hline At home, I use electricity without worrying about consumption. & 2.28 & 1.20 \\
\hline I tend to use reusable bags when I go shopping. & 3.87 & 1.19 \\
\hline $\begin{array}{l}\text { I forget to separate and dispose of paper in special containers, I throw it } \\
\text { away along with the other garbage. }\end{array}$ & 1.94 & 1.18 \\
\hline I buy organically-grown fruit. & 3.11 & 1.08 \\
\hline Personally, I care about the rational consumption of water at home. & 3.63 & 1.18 \\
\hline $\begin{array}{l}\text { I separate and dispose of glass waste in containers specially marked for this } \\
\text { purpose. }\end{array}$ & 4.10 & 1.23 \\
\hline
\end{tabular}


These results show that the behaviours future preschool teachers practice the most are behaviors related to saving energy and water, which is not surprising given that most of them still do not have their own income. This confirms the fourth hypothesis. The same results were obtained by Rončević and Cvetković (2016) and they concluded that students were most often involved in behaviours that were economically more profitable for them. Furthermore, Heyl, Diaz, Cifuentes (2013) found in the population of Chilean students that the most commonly practiced behaviours were those related to turning off the tap and turning off the lights, and the least related to buying recycled products due to the inability to afford them. Eagle et al. (2015) also came to the results that students mostly practiced those behaviours that required a minimal lifestyle change, such as turning off lights, using energy saving light bulbs, etc.

In order to test the last hypothesis, a t-test and analysis of variance for independent samples were performed. In determining whether there are statistically significant differences among participants regarding the year of study, at-test was performed for independent samples where it was found that there were no statistically significant differences on any of the dependent variables.

Furthermore, an analysis of variance was performed for the independent samples on all the statements. The results show that there is a statistically significant difference on two out of the total number of variables regarding to the place of residence of future preschool teachers. A statistically significant difference is visible in the statement $I$ turn off the devices rather than leaving them on the charger $(\mathrm{F}(2,263)=3.421, \mathrm{p}<0.05)$, where the partial $\eta 2$ is 0.025 , which indicates a small correlation between the assessment of the statement and the place of residence. A post hoc test Hochberg GT2 found that there was a difference between rural and large city participants. The participants from rural areas showed more frequent pro-ecological behaviour in this statement $(\mathrm{M}=3.63$; $\mathrm{SD}=1.24)$ than respondents from a large city $(\mathrm{M}=3.16 ; \mathrm{SD}=1.34)$. The next statistically significant difference was found on the statement $I$ buy organicallygrown fruit $(\mathrm{F}(2,263)=3,867, \mathrm{p}<0.05)$, where the partial $\eta 2$ is 0.029 , which indicates a small correlation between the assessment of this statement and the place of residence of the participants. A post hoc test Hochberg GT2 found that there was a statistically significant difference between participants from small and large cities. The participants living in a small town assessed this pro-ecological behaviour more often $(\mathrm{M}=3.42$; $\mathrm{SD}=1.00)$ than participants from a large town $(\mathrm{M}=2.94 ; \mathrm{SD}=1.01)$. This result can be attributed to the fact that smaller cities may have greater availability and choice of organic products than larger cities, hence, such a result. 
For the independent variable age, a statistically significant difference was found on the statement $I$ find separating and disposing of garbage for recycling on eco-islands boring $(\mathrm{F}(2,263)=4,772, \mathrm{p}<0.05)$, where the partial $\eta 2$ is 0.036 , which indicates a small correlation between the assessment of the statement and the age of the participants. The Games-Howell post hoc test found that there was a statistically significant difference between participants aged 18 to 19 and the ones aged 20 to 21. The participants aged 18 to 19 show a greater tendency to this non-ecological behavior $(\mathrm{M}=2.35 ; \mathrm{SD}=1.19)$ than the participants aged 20 to $21(\mathrm{M}=1.86$; $\mathrm{SD}=1.01$ ). No statistically significant difference was found on the other independent variables. Although some previous research found differences regarding to gender (Cifrić, 1997; Heyl, Diaz, Cifuentes, 2013; Rončević, Cvetković, 2016) in this study it was not possible to conduct statistical analyzes since gender was not relevant independent variable for further processing due to the predominance of female participants. Regarding to the results above, the last hypothesis is partially accepted.

\section{CONCLUSION}

According to the results of the research presented in this paper, the largest percentage of future preschool teachers agree that today's society strives for sustainable development. Furthermore, regarding the familiarity with the concepts arising from the concept of sustainable development, it can be concluded that most future preschool teachers are familiar with the concepts themselves and their meanings. In the examination of pro-ecological behaviour, it is evident that there are minimal differences, but it can be concluded that most future preschool teachers manifest pro-ecological behaviours related to energy and water savings. This research primarily sought to examine what knowledge do future preschool teachers have. In order to obtain a broader picture of the familiarity of future preschool teachers with the concept of sustainable development, it is advisable to conduct research on a larger sample. In addition, the authors advise that the following research should include a sample of male and female participants, although it is clear that, in that case, the population will not be able to consist of participants in early childhood profession because according to statistics there is a very small percentage of men in that profession. It is definitely recommended that the future research also include graduate students, in order to determine whether there are differences in attitudes towards sustainable development issues regarding the year and level of study. 


\section{REFERENCES}

1. Afrić, K. (2002). Ekološka svijest - pretpostavka rješavanja ekoloških problema. Ekonomski pregled, 53(5-6): 578-594.

2. Ajzen, I. (1991). The theory of planned behavior. Organizational behavior and human decision processes, 50(2): 179-211.

3. Ajzen, I., Fishbein, M. (1980). Understanding attitudes and predicting social behavior. Englewood Cliffs, NJ: Prentice-Hall.

4. Anđić, D., Tatalović-Vorkapić, S. (2015). Kako mjeriti održivo ponašanje? Adaptacija i validacija Upitnika o održivom ponašanju. Revija za sociologiju, 45(1): 69-97.

5. Anđić, D. (2007). Paradigmatski aspekti problematike okoliša i odgoj za okoliš i održivi razvoj. Metodički ogledi, 14(2): 9-23.

6. Boon, H. J. (2010). Climate Change? Who Knows? A Comparison of Secondary Students and Pre-service Teachers. Australian Journal of Teacher Education, 35(1): 104-120

7. Cifrić, I. (1997). Etos odgovornosti i ekološka osjetljivost, Socijalna ekologija, 6(3): 253-272.

8. Cifrić, I. (2001). Eksurs o održivom razvoju. Socijalna ekologija: časopis za ekološku misao i sociologijska istraživanja okoline, 10(3): 157-170.

9. Eagle, L., Low, D., Case, P., Vandommele, L. (2015). Attitudes of undergraduate business students toward sustainability issues. International Journal of Sustainability in Higher Education, 16(5): 650-668.

10. Eaton, M., Davies, K., Williams, S., MacGregor, J. (2017). Why sustainability education needs pedagogies of reflection and contemplation. In: M. Eaton, J. H. Hughes, J. MacGregor, (eds.). Contemplative approaches to sustainability in higher education - Theory and Practice. London: Routledge, Taylor \& Francis Group.

11. Effeney, G., Davis, J. (2013). Education for sustainability: A case study of pre-service primary teachers' knowledge and efficacy. Australian Journal of Teacher Education, 38(5): 32-46.

12. Field, A. (2013). Discovering Statistics Using IBM SPSS Statistics. London: Sage Publication.

13. Drljača, M. (2012). Koncept održivog razvoja i sustav upravljanja. Međunarodni skup Nedelja kvaliteta, Kvalitet i izvrsnost, FQCE-Fondacija za kulturu kvaliteta i izvrsnost, Beograd, 1(1-2): 20-26. Retrieved from: https://bib.irb.hr/datoteka/580157.Koncept odrivog razvoja i sustav upravljanja.pdf (5.11.2020.)

14. Herceg, N. (2013). Okoliš i održivi razvoj. Zagreb: Synopsis.

15. Heyl, M., Diaz, E.M., Cifuentes, L. (2013). Environmental attitudes and behaviors of college students: a case study conducted at a chilean university. Revista Latinoamericana de Psicología Volumen 45(3): 487-500.

16. Keles, Ö. (2017). Investigation of Pre-Service Science Teachers' Attitudes towards Sustainable Environmental Education. Higher Education Studies, 7(3): 171-180.

17. Kollmuss, A., Agyeman, J. (2002). Mind the gap: Why do people behave environmentally and what are the barriers to pro-environmental behaviour. Environmental Education Research, 8(3): 239-260. 
18. Kostova, Z., Atasoy, Z. (2008). Methods of successful learning in environmental education. Journal od Theory and Practice in Education, 4(1): 49-78.

19. Mathebula, M. (2018). Engineering Education for Sustainable Development: A Capabilities Approach. London and New York: Routledge.

20. Pavić-Rogošić, L. (2010). Održivi razvoj. Odraz. 1-13. Retrieved from: http://odraz.hr/ media/21831/odrzivi razvoj.pdf (5.11.2020.)

21. Pejanović, R. (2014). Održivi razvoj i visoko obrazovanje. Ljetopis naučnih radova, 38(1): 5-18.

22. Petz, B., Kolesarić, V., Ivanec, D. (2012). Petzova statistika. Zagreb: Naklada slap.

23. Popović, R. (eds) (2015). Metodološko uputstvo za implementaciju programa „Obrazovanje za održivi razvoj“. Podgorica: Zavod za školstvo.

24. Rončević, N., Cvetković, K. (2016). Students' Attitudes and Behaviours in the Context of Environmental Issues. Socijalna ekologija, 25(1-2): 11-37.

25. Rončević, N., Ledić, J., Ćulum, B. (2008). „Nisam siguran što je, ali je bitno - analiza stavova studenata Sveučilišta u Rijeci o održivom razvoju. Suvremene teme: međunarodni časopis za društvene i humanističke znanosti, 1(1): 62-75.

26. Rončević, N., Rafajac, B. (2012). Održivi razvoj - izazov za sveučilište? Rijeka: Filozofski fakultet u Rijeci.

27. Schwartz, S. H. (1977). Normative Influences on Altruism, Advances in Experimental Social Psychology, 10(1): 221-279.

28. Summers, D., Cutting, R. (eds) (2016). Education for Sustainable Development in Further Education - Embedding sustainability into teaching, learning and the Curriculum. London: Palgrave Macmillan.

29. Uzelac, V. (2002). Obrazovanje studenata za okoliš. Zagreb: HPKZ.

30. Vukelić, N., Rončević, N., Vinković, A. (2018). Jesu li budući nastavnici spremni za integraciju obrazovanja za održivi razvoj u nastavu? In: E. Dedić Bukvić, S. Bjelan-Guska, (eds) Ka novim iskoracima u odgoju i obrazovanju. Zbornik radova sa 2. Međunarodne znanstveno-stručne konferencije, 2(2): 326-338. 


\section{POIMANJE ODRŽIVOGA RAZVOJA I PROEKOLOŠKO PONAŠANJE BUDUĆIH ODGOJITELJA}

\section{SAŽETAK}

$U$ radu se determinira održivi razvoj $i$ ističe se važnost obrazovnih ustanova u proklamiranju održivoga razvoja. Nadalje, provedeno je istraživanje čiji je cilj bio utvrditi poimanje održivoga razvoja $i$ upoznatost s određenim terminima te učestalosti određenoga proekološkoga ponašanja kod budućih odgojitelja. Uzorak u ispitivanju sačinjavali su studenti preddiplomskoga studija Rani i predškolski odgoj $i$ obrazovanje Sveučilišta u Zagrebu $(N=266)$. Prema dobivenim rezultatima budući se odgojitelji slažu da današnje društvo treba težiti održivom razvoju. Uz to, budući odgojitelji najviše prakticiraju ona proekološka ponašanja koja se odnose na uštedu energije i vode.

Ključne riječi: održivi razvoj, obrazovna ustanova, istraživanje, budući odgojitelji, proekološka ponašanja. 